Paedagogia Christiana

2/46 (2020) - ISSN 1505-6872

\begin{abstract}
Janusz Mariański. Godność ludzka - wartość doceniona czy puste słowo? Studium socjopedagogiczne. Warszawa: Warszawskie Wydawnictwo Socjologiczne, 2019, ss. 338.
\end{abstract}

DOI: http://dx.doi.org/I0.12775/PCh.2020.026

W dobie nowoczesności zauważa się, że problematyka godności człowieka coraz częściej podejmowana jest w dyskusjach bioetycznych, zwłaszcza jeśli chodzi o podkreślenie szczególnej pozycji człowieka lub wyznaczenie absolutnych granic tego, co można z ludźmi zrobić. W określonych kontekstach dyskutuje się o (własnym) szacunku i samostanowieniu ludzi lub o ich integralności (fizycznej i psychicznej). Czasami odniesienie się do godności ludzkiej nie oznacza godności jednostek, ale raczej ochronę określonego obrazu człowieka lub godności ludzkości jako gatunku.

W wymiarze moralnym pojęcie godności człowieka jest zwykle rozumiane w taki sposób, że wszyscy ludzie cieszą się godnością w sposób ciągły. Ktokolwiek mówi o godności ludzkiej, na ogół ma na myśli to, że wszyscy członkowie gatunku ludzkiego mają godność, nie może być „więcej” ani „mniej” godności ludzkiej i że nie można zdobyć ani utracić godności ludzkiej. To też odróżnia moralną koncepcję godności człowieka, tak jak została ona paradygmatycznie sformułowana przez I. Kanta, od innych ujęć pojęcia godności. Warto podkreślić, że koncepcja Kanta jest istotna dla współczesnego rozumienia godności ludzkiej, która ukształtowała na przykład niemiecką ustawę zasadniczą („Godność człowieka jest nienaruszalna”). Według Kanta godność człowieka opiera się na tym, że ludzie mają zdolność do rozumnego i moralnego działania. Twierdzi on, że ludzie mają zatem „nieporównywalną wartość" lub godność, w przeciwieństwie do innych żywych istot.

W powyższy dyskurs rozumienia pojęcia godności człowieka wpisuje się najnowsza publikacja ks. prof. zw. dr. hab. Janusza Mariańskiego: Godność 
ludzka - wartość doceniona czy puste słowo? Studium socjopedagogiczne. Janusz Mariański, emerytowany profesor socjologii religii i socjologii moralności w Instytucie Socjologii Katolickiego Uniwersytetu Lubelskiego Jana Pawła II i wykładowca w Wyższej Szkole Nauk Społecznych z siedzibą w Lublinie, wybitny badacz, uhonorowany najwyższą godnością akademicką - tytułem doktora honoris causa Uniwersytetu Śląskiego, od kilku dekad publikuje prace dotyczące katolicyzmu polskiego, czy szerzej - religijności Polaków, zarówno przed, jak i po 1989 roku, w okresie przemian społeczno-ustrojowych, gospodarczych i kulturowych. Jest uznanym znawcą wspomnianej problematyki zarówno na gruncie polskim, jak i w zachodnioeuropejskich środowiskach akademickich. Opublikował ponad 60 książek i około 1500 artykułów, w tym ponad 30 artykułów w językach obcych.

Recenzowana monografia Janusza Mariańskiego opisuje kategorię godności ludzkiej w różnych kontekstach badań interdyscyplinarnych. Takie badania mają swoją szczególną relewancję, jeśli uwzględnimy fakt, że we współczesnych społeczeństwach, w których zakwestionowano istnienie uniwersalnych i obiektywnych wartości, odrzucono pojęcie natury ludzkiej, coraz trudniej jest mówić o godności. Tu autor słusznie podkreśla, że chociaż godność jako wartość jest przedmiotem zainteresowań różnych dyscyplin naukowych: filozofii, prawa, teologii, psychologii, pedagogiki i innych, o tyle na gruncie socjologii problematyka godności ludzkiej jest bardzo rzadko podejmowana. Stąd też jego słuszny postulat, że ten istniejący deficyt powinien skłaniać do podejmowania na szerszą skalę badań empirycznych nad godnością ludzką w życiu społecznym.

Ze względu na fakt, iż współczesna kultura przyczynia się do relatywizowania lub naruszania godności osób należących do różnych warstw społecznych, Janusz Mariański w niniejszej monografii analizuje różne konteksty społeczne funkcjonowania wartości godnościowych, rozumienie pojęcia godności przez współczesnych Polaków, sposoby jej uzasadniania, oceny osób o wysokim poczuciu godności własnej oraz sytuacje, w których najczęściej dochodzi do naruszania godności drugiego człowieka, mechanizmy nadawania i odbierania innym godności w sensie społeczno-moralnym.

Publikacja Janusza Mariańskiego - poza spisem treści, przedmową i posłowiem prof. Andrzeja Wójtowicza z Instytutu Socjologii UKSW, wstępem, zakończeniem, wykazem skrótów, bibliografią i notą bibliograficzną - zawiera cztery rozdziały.

W rozdziale pierwszym zatytułowanym: „Godność osobowa, osobowościowa i osobista”, autor kieruje uwagę na godność jako wartość związaną $\mathrm{z}$ osobą ludzką, mającą cechę przyrodzoną, niezmienną, obiektywną, trwałą 
i przypisaną, której nie wolno naruszyć ani się jej pozbyć. Godność osobowa jest niezależna od tego, jak się zachowujemy i jakie wartości uznajemy, stanowi wyraz naszego człowieczeństwa. Z kolei godność osobowościowa i osobista wiąże się z postępowaniem człowieka zgodnym z jego przekonaniami i systemem wartości, a także z obroną wyznawanych zasad i norm, podlega zmianom. Należy podkreślić, że ujęcia godności ludzkiej rozważane w aspekcie teologicznym, filozoficznym, psychologicznym, pedagogicznym i socjologicznym nie są ze sobą sprzeczne. Co więcej, takie badania interdyscyplinarne ukazują integralny obraz kategorii godności ludzkiej. Warto tu też zaznaczyć, że odrzucenie uzasadnień teologicznych prowadziłoby w konsekwencji do zubożenia całościowej koncepcji godności osoby ludzkiej, ponieważ osoba nie może stać się przedmiotem użycia, na podobieństwo użycia zwykłej rzeczy.

W rozdziale drugim: „Pojęcie godności ludzkiej i sposoby jej uzasadnienia”, Janusz Mariański zwraca uwagę na wartości godnościowe, które znajdują się na linii głębokiej potrzeby dowartościowania siebie. Przyznanie każdej jednostce ludzkiej autonomicznej wartości i niepowtarzalności jest przejawem pogłębiania się tendencji personalistycznych we współczesnym świecie. W wymiarze ontologicznym godność przysługuje wszystkim ludziom i dlatego z natury są sobie równi. W uzasadnianiu godności ludzkiej będącej niezbywalną wartością życia istotne są zarówno przesłanki filozoficzne, jak i teologiczne. Te aspekty nie powinny być sobie przeciwstawiane, ponieważ są to tylko dwa punkty spojrzenia na tę samą prawdę o godności i wielkości człowieka. Przypisują one godności naturę ontologiczną i aksjologiczną.

W rozdziale trzecim zatytułowanym: „Indywidualne i społeczne sytuacje zagrażające godności ludzkiej”, autor analizuje godność jako wartość społeczną. Odnoszona jest ona do warunków i sytuacji, w jakich żyje i działa człowiek. Opierając się na przeprowadzonych badaniach, Janusz Mariański podkreśla z jednej strony, że w pluralistycznym i globalizującym się świecie rola sytuacji współczesnych w kształtowaniu postaw i zachowań godnościowych wydaje się wzrastać. $Z$ drugiej zaś strony można $\mathrm{z}$ łatwością zauważyć, że w obszarach dotyczących życia politycznego, gospodarczego, społecznego i kulturalnego dochodzi do naruszeń godności ludzkiej. Te poszczególne dziedziny życia człowieka powinny być oceniane ze względu na ludzką godność według adekwatnych kryteriów, czy jest ona respektowana i dostatecznie chroniona.

W ujęciu teologicznym wszystko to, co narusza godność ludzką i sprowadza człowieka do roli przedmiotu i narzędzia, należy interpretować jako naruszenie prawa Bożego, ponieważ źródłem godności człowieka jest Bóg, 
który stworzył go na swój obraz i podobieństwo. Akceptacja każdej osoby, takiej jaka ona jest, z jej wszystkimi zdolnościami i przyzwyczajeniami, a także z tym, co wynika z jej ułomności fizycznej czy psychicznej, wymaga humanitarnego podejścia i solidarności ludzkiej, opiera się na chrześcijańskim obrazie człowieka. Godność osoby ludzkiej, jak podkreślał też niejednokrotnie w swoim nauczaniu Jan Paweł II, nigdy nie może być uzależniana od zwykłych osiągnięć ludzkich. Odnosi się to przede wszystkim do tych osób, które nie są w stanie ze względu na swoją ułomność fizyczną czy psychiczną odnosić sukcesów. Dlatego tej właśnie grupie ludzi należy się sympatia ze strony bliźnich, jak i różnych instytucji charytatywnych, kościelnych czy państwowych.

Bardzo ważny i niezwykle aktualny jest rozdział czwarty omawianej monografii: „Wychowanie ku wartościom godnościowym”, który to aspekt jest przedmiotem sporów i dylematów na poziomie codziennych dyskursów. Janusz Mariański podkreśla tu, że zarówno godność osoby ludzkiej, jak i godność osobowościowa i osobista są istotnymi i potrzebnymi kategoriami w opisie kondycji człowieka i społeczeństwa, a przede wszystkim w procesie wychowania moralnego dzieci i młodzieży.

W powyższym kontekście autor zaznacza dalej, że proces przemian wartości nabiera tempa i niesie ze sobą szanse i zagrożenia. Im więcej w społeczeństwie otwartym zagwarantowanej i rzeczywistej wolności, tym więcej jest możliwości współkształtowania zmian w świecie aksjologicznym. Relewantne jest tu wychowanie ku wartościom mającym charakter uniwersalny. Warto jednak zaznaczyć, że promowaniu wartości progodnościowych nie sprzyja $\mathrm{w}$ dobie globalizacji nowoczesnych społeczeństw szerząca się kultura relatywizmu moralnego. Jest to groźna przeszkoda w wychowaniu do uniwersalnych wartości godnościowych, które niewątpliwie bardziej zakorzenione są w Transcendencji, niż inne wartości mające charakter zmienny i nietrwały.

Podsumowując zawartość merytoryczną monografii Janusza Mariańskiego, należy stwierdzić, że jego przemyślenia i analizy wokół problematyki godności ludzkiej zasługują na uznanie. Autor - jako wybitny znawca socjologii religii i socjologii moralności - przybliżył Czytelnikowi to zagadnienie w sposób niezwykle klarowny i uporządkowany również pod względem metodologicznym. Interdyscyplinarne analizy wymagały wieloaspektowego spojrzenia i dotarcia nie tylko do literatury polskojęzycznej. Janusz Mariański cytuje także prace niemiecko- i angielskojęzyczne uznanych autorów, co sprawiło, że z perspektywy socjologicznej jego analizy przyczyniły się niewątpliwie do poszerzenia i pogłębienia dotychczasowych badań. 
Wkład autora można określić tu jako wyjątkowy, ponieważ zagadnienie godności ludzkiej stanowi przedmiot zainteresowania różnych dyscyplin naukowych, ale niestety w literaturze socjologicznej nie zajmuje jeszcze należnego miejsca. Stąd też Janusz Mariański, analizując tę niełatwą problematykę, zastosował w sposób konstruktywny kryteria instrumentu hermeneutycznego, zwłaszcza pod kątem hermeneutyki egzystencjalnej.

Konkludując, jego publikacja opisująca kategorię godności jako wartość stanowiącą fundament wychowania personalistycznego jest niebagatelnym wyzwaniem dla wszystkich biorących aktywny udział w życiu gospodarczym, zawodowym i politycznym, w warunkach nowoczesnych społeczeństw pluralistycznych i narastającego relatywizmu moralnego. Zachęcam wszystkich zainteresowanych do wnikliwej lektury.

Cyprian Rogowski*

ORCID: 0000-0002-7382-2203

Vechta, Niemcy

\section{Helena Słotwińska. Pedagogiczny wymiar życia sakramentalnego. Studium z pedagogiki religii. Lublin: Wydawnictwo KUL, 2019,} ss. 316.

DOI: http://dx.doi.org/I0.12775/PCh.2020.027

Recenzję rozpoczynam od przywołania dwóch faktów. Pierwszym jest opinia bpa koszalińsko-kołobrzeskiego Edwarda Dajczaka. Dostrzega on wiele słabości w Kościele katolickim w Polsce i wzywa do zmiany form duszpasterzowania, zanim nie będzie za późno. Na pytanie w jednym z wywiadów, jakie są najczęstsze powody odejścia młodych ludzi z Kościoła, odpowiedział: „Obawiam się, że sytuacja w domu rodzinnym i sposób, w jaki prowadzone jest duszpasterstwo, powoduje, że młodzi tak naprawdę wiary dla siebie nie odkrywają. W rodzinie, która nie daje doświadczenia Boga, dziecko nie może zobaczyć, że Bóg kształtuje życie najbliższych. Kościół zaś często przygotowanie sakramentalne zbytnio zawęża do wyjaśniania pojęć i nauczania prawd wiary, zamiast zdecydowanie bardziej wykorzy-

* Ks. prof. zw. dr hab. Cyprian Rogowski, Institut für Katholische Theologie, Fakultät III Geistes- und Kulturwissenschaften; Uniwersytet Vechta; e-mail: cyprian.rogowski@uni-vechta.de. 